\title{
McGill University and Quebec City in the 1960s
}

\section{by Peter F. McNally}

\begin{abstract}
In Canada and throughout the Western world, the 1960s was a tumultuous decade of student unrest and social/political upheaval. For Quebec, the 1960s was also the decade of la Revolution tranquille/Quiet Revolution, when francophone society's self-definition underwent fundamental change. For McGill University, the decade's changing environment required enormous adaptation: maintaining and extending academic programs and standards, restructuring governance and administration, expanding the physical plant, accommodating growing enrolment, seeking adequate funding, and adjusting to Quebec's changing reality. A wide range of primary and secondary sources is available in recounting the story of McGill's role in Quebec during the 1960 s.
\end{abstract}

\section{RESUMÉ}

AuCanada ainsique partout ailleurs danslemondeoccidental, les années 1960 furent une décénnie d'agitationétudiante et de perturbations sociales et politiques. Au Québec, les années 1960 furent aussi la décénnie de la Révolution tranquille, durant laquelle la manière dont la société francophone se définissait elle-même a subi un changement fondamental. Dans le cas de l'Université McGill, les transformations de l'environnement durant cette période ont nécessité énormément d’adaptation: le maintien et l'expansion des programmes et des normes académiques, la restructuration de la gouvernance et de l'administration, l'agrandissement des installations, l'accomodation du nombre croissant d'inscriptions, les efforts déployés pour assurer un financement adéquat, et l'ajustement de l'Université aux changements vécus par le Québec. Un large éventail de documentation primaire et secondaire est disponible pour relater l'histoire du rôle de McGill au Québec durant les années 1960.

1 970 brought crisis to McGill University as it did to Quebec and Canada-but in different months, for different reasons. For McGill June brought a funding crisis, whereas for the province and the country October brought the FLQ crisis. Both at the time, and subsequently, 1970 would generally be identified with la crise d'Octobre/ October Crisis and the FLQ-Front de libération du Québec/Quebec Liberation Front. For McGill, however, the June crisis was initially more important_involving as it did the internal operations of the University and relations with Quebec City. At the time, the October FLQ crisis, although centered upon Quebec with national and even international ramifications, affected only peripherally most individuals and institutions such as McGill. The long term consequences from both crises would reverberate throughout the final decades of the century and beyond.

On May 12, 1970 a new Quebec government was sworn into office-having defeated the previous government two weeks earlier in a Quebec general election-with Robert Bourassa as Premier (1970-1976) and Guy St. Pierre as Minister of Education. Shortly thereafter annual operating grants from the government to provincial universities were announced. To McGill's surprise, its Quebec grant would be nearly \$3M less than anticipated: $\$ 25.2 \mathrm{M}$ instead of $\$ 28 \mathrm{M}$. As the University had already budgeted for a $\$ 3 \mathrm{M}$ shortfall between its revenue and expenditures, the result would be a $\$ 6 \mathrm{M}$ annual deficit to be covered by investments and gifts. As the operating budget was less than $\$ 60 \mathrm{M}$ - and less than $\$ 45 \mathrm{M}$ if research grants are excluded-this shortfall represented a disturbingly high proportion of anticipated income. Principal H. Rocke Robertson (1962-1970) brought the matter immediately to the Board of Governors, which on June 25 established a Special Committee to "explore and develop alternative models for the operation of the University within the constraints foreseen in the next five years." Composed of Board, Senate, faculty, and student representatives, this committee would be Robertson's last initiative before stepping down as Principal on August 21. He worked in consultation with his successor Robert E. Bell (1970-1979), who continued the work of the Special Committee. ${ }^{1}$

\section{The 1960s}

Robert Bell inherited a University whose internal and external realities had been deeply altered during the 1960 s. 
For the Western world generally, including Canada, the '60s was a decade of great prosperity and profound cultural change. The youth generation created a counter-culture movement characterized by anti-war sentiments and opposition to nuclear weapons and the Viet Nam war, as well as by drugs, distinctive music, and relaxing sexual attitudes-among other things. Public demonstrations, sometimes violent, occurred with great regularity on behalf of causes such as an increased role for students in university government. Well educated and prosperous young flag bearers of the post World War II baby boom generation took for granted that they would soon take charge of the world. Ironically, rising youth activism coincided with collapse of the baby boom, enabled in part by female oral contraceptives - the "pill". Feminism and the rising profile of women in society would influence all aspects of late $20^{\text {th }}$ century life, including universities, as part of a major social transition. Computers and automation also emerged as a regular part of daily life.

For Canada, the ' 60 s were notable for, among other things, enhanced government involvement in society-specifically health, education, and welfare. Both a national health insurance plan and the Canada Pension Plan (CPP) were introduced by Ottawa. Appreciating that the country's future depended upon an educated population able to cope with current and projected needs, particular attention was placed upon higher education which experienced a golden age of financial support unprecedented in Canadian history. Democratization of Canadian higher education and its participation in mass education would now begin. ${ }^{2}$

Within Quebec, la Revolution tranquille/Quiet Revolution was launched by the 1960 defeat of the long serving Union nationale party-led for most of its tenure by Maurice Duplessis (1890-1959)-and its replacement by the Liberal government of Jean Lesage (1912-1980). Laissez-faire social and economic policies of the past were replaced by activist government intervention. The Roman Catholic religion as the vehicle for expressing and maintaining French-Canadian nationalism-organizing and operating its social, cultural, and educational life - was thrown aside in favour of secular nationalism. The French language - not the Church - would now emerge as the primary vehicle for expressing FrenchCanadian-Québecois(e)_nationalism. Quebec's government would increasingly conduct itself as a "national" government-organizing economic, social, cultural, and educational activities in support of the majority Francophone population. In parallel, Montreal's Francophone business elite began supplanting Anglophone business leadership as the city's financial activity became increasingly more focused upon Quebec and less upon Canada. The province developed the Quebec Pension Plan (QPP), distinct from the CPP. An attitude of "maitres chez-nous"-masters of our own house-was in full swing. As for the two hundred year old English-language community, it began wondering about its future in the province as proposals emerged for promoting the French language and curtailing English. Proposals also emerged for rebalancing Quebec's role within Confederation, or even separating the Province completely from Canada. Although advocates of these new proposals were generally peaceful and constitutional in their approach, radical groups did emerge advocating violent change.

\section{Higher Education}

Education emerged as a particular concern of the province. Although there had been a Department of Instruction publique/Public Instruction from 1868 to 1874, for ninety years thereafter separate Catholic and Protestant committees oversaw Quebec's educational affairs at the school level; at the post-secondary level there was no effective overview. In 1964, a Department of Education was created. Armed with the Report of the Parent Commission royale d'enquête sur l'enseignement/Parent Royal Commission of Enquiry on Education (1965/66), the new Department concerned itself immediately with higher education generally and universities specifically in a way never previously experienced by McGill and its sister institutions. Developing a Quebec system of higher education emerged quickly as a priority.

This newly awakened concern with higher education would have considerable - but different - impacts upon both Anglophone and Francophone communities. Francophone higher education had long revolved around two distinct types of institutions: collèges classiques/classical colleges and universities. Both types of institutions were private, charged fees, and were run by teaching and administrative staffs composed largely or exclusively of Roman Catholic clergy. Collèges classiques provided both high school diplomas and baccalaureate degrees, wed closely to the classical Trivium (literary \& philosophical) and Quadrivium (mathematical \& musical) curriculum. Despite some success at modernizing and introducing science and the social sciences, a strong humanities and religious orientation suffused the curriculum. By comparison, the province's three French-language universities - Laval (origin 1663, established 1852), Montréal (origin 1878, established 1919), and Sherbrooke (established 1954)-defined themselves as graduate and professional institutions, requiring degrees from a collège classique for admission. University entrance would typically occur after successful completion of 15 years of study in primary school and collège classique, the latter serving as undergraduate faculties of arts for their affiliated universities. Although this system had its undoubted strengths and benefits, it was inherently elitist and did not lend itself to late $20^{\text {th }}$ century curricula and democratic, mass education. Nor did it lend itself to developing research intensity. The approximately 100 collèges classiques, each averaging a few hundred students, with their exclusive atmospheres, arcane curricula, and fees were uninviting for most people. As the required path 
to university admission, they were too parochial, while the universities themselves were too narrowly focused. ${ }^{3}$

For the Anglophone community, including the Protestant school boards that dominated its primary and secondary education, long-standing practice ensured general compatibility with curriculum found elsewhere in English-speaking Canada and the world. After successfully completing 11 years of primary and secondary schooling, students could enter university as undergraduates. Upon successful completion of 4 years, or 3 years if university was entered after grade twelve, a Bachelor's degree would be conferred. Bishop's University (established, 1843) and Sir George Williams University (established, 1926) were primarily local, undergraduate teaching institutions, whereas McGill (established, 1821) was renowned for its undergraduate, graduate, and professional programs, and enjoyed a national and international reputation for teaching and research. All three accepted the German-American pattern of higher education, for which McGill earlier in the century had been a Canadian pioneer, and which called for a reformed liberal arts undergraduate program-humanities, social sciences, and science-superimposed upon which was a range of graduate and professional programs. That said, when the 1960s opened, Quebec's Anglophone universities like others across Canada, despite becoming more open and less elitist after World War II, were far from being democratic institutions of mass education. ${ }^{4}$

Quebec's solution to creating a higher education structure in line with contemporary practice of Anglophone Canada and the world, while paying homage to traditional Francophone educational heritage, was to create a unique blend of the two-borrowed and adapted from both sides. To begin with, Collèges classiques and their traditional curricula were swept away to be replaced during 1967/1969 by uniquely Quebec junior colleges, or CEGEPs, Collèges d'enseignement général et professionnel/Colleges of General and Professional Education. After finishing grade 11, both Anglophone and Francophone students would now proceed to these new institutions, granting diplomas in a wide range of technical and semi-professional occupations. In addition, they provided a mandatory route for university entrance through successful completion of a 2 year academic program. Unless designated as private, they were secular and charged no tuition fees.

As for universities, in the late ' 60 s Francophone institutions adopted Anglophone practice, becoming secular and adopting the German-American pattern of higher education: newly introduced undergraduate streams superimposed upon which were graduate and professional programs. Some professional programs such as Medicine and Law would be required to accept a portion of their students directly from CEGEPs. In anticipation of significantly increased Francophone enrolment, Quebec initiated the Université du Québec (UQ) system (established, 1968) with branches across the province-the centrepiece being the establishment in 1969 of Université du Québec à Montréal (UQAM). For McGill and other Quebec universities, undergraduate degrees would become standardized as 3 year programs. Despite initial trepidation and uncertainty, shared equally by Anglophones and Francophones, adoption of the new structures and patterns proceeded smoothly and with relative calm. CEGEPs did, however, require creative solutions by the Anglophone community, which unlike the Francophone community, had no collèges classiques for quick and easy conversion to junior colleges. Unlike their sister Francophone institutions, McGill and the other Anglophone universities expected enrolment to remain level or even fall, due to demographic decline of the English-speaking community.

\section{McGill University}

For McGill, the decade opened in 1960 with justifiable concern about its place in the world, despite appearing strong and healthy on the surface. On the positive side, was its strong international, academic reputation and reasonable claim to being Quebec's and possibly also Canada's leading university - with graduate enrolment accounting for $12 \%$ of 8,000 students, research grants representing $20 \%$ of the annual budget, and $\mathrm{PhD}$ graduates constituting $25 \%$ of the Canadian total. Principal F. Cyril James (1903-1973), supported by a small cadre of secretaries and assistants, provided intelligent and competent one-man leadership for the University. Financial support from Montreal's Anglophone community was unwavering, and provincial government support was growing slowly but steadily.

There was, however, also cause for worry. In acknowledgement of the growing importance of higher education, sharp competition was rising across the country as most other provinces began supporting their universities much more generously than Quebec. McGill's physical plant was old and increasingly inadequate both in quality and quantity, and its salaries had not kept pace with the rest of the country so that in 1960 professors' pay ranked only $21^{\text {st }}$ among Canadian universities. In some quarters, the University was considered to have an inflated reputation far exceeding reality, in others it was dismissed as merely a training ground for Montreal's Anglophone business and social elite. A major problem was financial: the inability of traditional funding sources - fees, gifts, and endowments - to keep pace with expenditures. Because of a jurisdictional dispute between the province and Ottawa, Quebec's universities were prohibited from receiving higher education funds provided by the federal government.

In 1962, two significant events marked a turning point for McGill, one was local and the other of provincial and national significance. The latter event was a negotiated settlement between Ottawa and Quebec City over university funding, whereby federal money for universities instead of 
going directly to institutions would be funnelled through the province-eventually all provinces-and distributed according to its own standards. McGill received immediately a windfall of $\$ 5,866,378$-its share of federal funding withheld for ten years at Quebec City's insistence. With this money, along with greatly increased provincial operating and capital grants, plus continuing private support from alumni and friends, McGill embarked upon a concerted program of growth and enhancement. The local event was the retirement of long serving Principal Cyril James, and the succession of Rocke Robertson under whose patrician, energetic, and intelligent leadership McGill was transformed academically, geographically, administratively, constitutionally, and financially. His leadership also positioned McGill effectively in dealing with the social and political turmoil of the era.

Armed with its strong tradition of academic achievement, McGill began upgrading and strengthening every faculty and department. Established faculties such as Medicine and Arts \& Science were rejuvenated through revised curricula and the hiring of young faculty. Two new faculties were created through reconstituting existing departments: Education (1965) and Management (1968). Engineering continued a policy begun in the '50s of reorienting departments towards research. McGill University Press founded in 1961 and reorganized in 1968 as McGill-Queen's University Press-in partnership with Queen's University, Kingston, Ontario-immediately established a reputation for producing important and widely discussed books. Although enrolment had nearly doubled by 1970 to 14,500 , the University remained a medium-sized institution. As for the Faculty of Graduate Studies and Research, between 1960 and 1970, its enrolment doubled to $24 \%$ of the student body, and research grants rose by $6 \%$ to $26 \%$ of the total University budget, or $\$ 15.6 \mathrm{M}$. Although awarded $\mathrm{PhDs}$ declined from $25 \%$ to $11 \%$ of the Canadian total, McGill retained its status as one of the country's leading producers of doctorates. Despite also growing competition, McGill held its position remarkably well. Indicative of its support for Quebec's new educational structure, between 1969 and 1974 the University conducted on its Sherbrooke St. campus a CEGEP program. ${ }^{5}$

The geography of the Sherbrooke St. campus was reconfigured with a massive building program - continuing into the mid '70s - that would accommodate teaching and research for decades to come. These projects overshadowed even McGill's pre-World War I building splurge. ${ }^{6}$ Among the new structures, additions to existing buildings, and major renovations, were:

Bishop Mountain

Hall and Gardner,

1962

McConnell, and

Molson Halls

(men's residences)

\begin{tabular}{ll}
1963 & $\begin{array}{l}\text { Roscoe Wing, Royal } \\
\text { Victoria College } \\
\text { (women's residence) }\end{array}$ \\
\hline \multirow{3}{*}{1965} & $\begin{array}{l}\text { Stephen Leacock } \\
\text { (Arts) } \\
\text { University Centre } \\
\text { (students) }\end{array}$ \\
\hline Arts Building \\
- significantly \\
remodeled
\end{tabular}

To facilitate and implement these academic and geographic changes, the University's administrative structure was expanded, centralized, and revamped at both the executive and bureaucratic levels beyond anything previously known, but without undermining McGill's reputation for lean and decentralized administration.The number of Vice-Principals was doubled from two to four. In addition to Macdonald College continuing to have a VP, there would now be three designated Vice-Principals: Academic, Administration, and Professional Faculties. A Director of Finance position was also created that in time would be raised to the rank of Vice-Principal. Opened in 1967, the F. Cyril James Administration building housed an emerging professional bureaucracy with University-wide employment classification grades and salary levels, along with career opportunities for 
non-academic administrative staff. New administrative units were created such as Information (1964), Personnel (1966), and Planning (1968). Indicative of the central role that computers and information technology would play at McGill and throughout society, in 1959 McGill acquired its first computer accompanied by strict warnings that it was to be the University's only computer! Overseeing this new technology three new units were created reporting to three separate Vice-Principals: (i) McGill Computing Centre in 1959 under VP Planning; (ii) Instructional Communication Centre in 1968 under VP Academic; and (iii) Management Information Systems in 1970 under VP Administration. ${ }^{7}$

A remaining question revolved around governance. How ought McGill-expanding rapidly and embracing mass education - to be governed? This question of authority within the University led to contentious debate-and even violence-as McGill felt its way through unchartered territory. Important inspiration for McGill and other Canadian universities came from the Duff-Berdabl Report (1966), sponsored jointly by the Association of Universities and Colleges of Canada (AUCC) and the Canadian Association of Universities of Teachers (CAUT). The Report recommended democratization of university structures through such things as admitting faculty and general public members onto boards of governors, and electing deans and departmental chairs for defined terms. Local encouragement came from a 1959 report by the McGill Association of University Teachers (MAUT) established in 1951 "to foster academic freedom, to involve the faculty in University activities and governance, and to improve the working conditions and salaries of teaching faculty and librarians". A 1966/67 joint Senate-Board committee report, implemented in September 1968, transformed both Board and Senate. Senate-with control and supervision over academic activities - was transformed from an appointed body of senior administrators and some academics to a body whose majority was now composed of academics elected by their peers, in addition to administrators, and governors' representatives. As for the Board of Governors - with final authority over administration and finance-its membership was widened to include elected senators, women, and representatives from diverse sectors of the community, along with traditional representatives of business and industry.

In short, McGill's governance and administration underwent a profound transformation from benevolent autocracy to collegiality. Faculty Councils and Departmental Meetings were established or reformed-to include all faculty members - with agendas, minutes, and formalized procedures. Deans and departmental chairs whose appointments had been solely at the discretion of the Principal usually until retirement or death, were now appointed for fixed terms of 3 to 5 years (renewable) on the recommendation of advisory committees. In his short term as Dean before becoming Principal, Robert Bell began the process of transforming the Faculty of Graduate Studies Council into a collegial body with representatives from virtually every academic department on campus.

Strangely enough, students were overlooked in these reforms even though Principal Robertson as early as 1963 had shared with colleagues insights about emerging American student radicalism. By 1965, McGill's enrolment had risen to 12,728-with the greatest growth being in the Faculty of Arts and Science - and a "Code of Student Disciplinary Procedures" was adopted. That same year, the radical Students for a Democratic University (SDU) movement began gaining control of student government and publications, and goading the administration into public confrontation. In 1966 the Arts and Science Course Guide created a sensation with pointed evaluations and criticisms of teaching, leading to creation in 1969 of the University Centre for Teaching and Learning. Protests, including sit-ins of Board Meetings and academic departments, were mounted against fee increases, the Viet Nam war, formation of the Faculty of Management, and American military research funding for Engineering. Support and encouragement for these protests came in part from young, recently hired faculty particularly in Arts. In 1968, the McGill Reporter was established as a vehicle for disseminating the administrations viewpoint and posting notices, since the student-run McGill Daily (established, 1911) showed itself increasingly unwilling to fulfill this role.

One person to emerge with particular notoriety during this era was an undergraduate English student, John Fekete (BA'68, MA'69), who in 1967 issued the two most provocative $\mathrm{McG}$ ill publications of the decade. The first was a September $25^{\text {th }}$ report, to the Joint Board-Senate Committee on University government, urging enhanced student participation in all aspects of University life. The second was a November $3^{\text {rd }}$ McGill Daily article, which raised a huge public outcry for quoting parts of an infamous defamation concerning American president Lyndon B. Johnston's alleged, and vividly depicted, sexual indignity upon the body of his assassinated predecessor, John F. Kennedy. The two issues became inextricably intertwined and led to student rallies and occupation of the principal's office. Although Fekete met defeat on the necrophilia article-failing to win general student support and receiving a sharp reprimand from the Senate Discipline Committee-he did win his argument on the role of students in University life. The Joint Committee issued a persuasive report pointing out that students were a constituent element of the University and should therefore play a significant role in University governance-along with faculty, administration, and community representatives. As a result, in September 1968 students started being elected to Senate. Although student representation on the Board would be legislated only in the next decade, Senate made a point of electing student representatives to the Board. Over the next several years, student representation on Board and Senate committees as well as faculty and departmental 
decision-making bodies and their committees would become commonplace.

Although student and faculty agitation continued even after introduction of these reforms, 1968 would in retrospect be the high water point of radicalism. Despite procedural skirmishes at Senate and the Board, radical agendas were thereafter never seriously advanced. Replacement of benevolent autocracy by effective collegial structures had removed an irritant and potential flashpoint. Radical agendas in Arts/ Social Science departments tapered off noticeably with the dramatic upgrading of library facilities - hitherto a source of great frustration - when McLennan and the rebuilt Redpath Libraries opened in 1969/70. The Departments of Economics \& Political Science, and Sociology were notable exceptions with their confrontations over curriculum development, and hiring and firing of staff. In 1969, a breakaway group from MAUT formed the McGill Faculty Union (MFU) that was never able to fulfill its goal of unionizing professors and librarians. The patience, fortitude, and lack of arrogance of Principal Robertson in listening and not over reacting to goadings and upheavals proved to be the correct strategy. Unlike those universities that engaged in rear-guard battles against admitting faculty and students into the decisionmaking process, McGill established internal domestic peace early on, thereby avoiding prolonged internecine warfare. This achievement of internal domestic peace was fortunate given the powerful debate that would rage within Quebec during the coming years and decades over language of education, and funding for higher education-issues over which McGill had little or no control, but which would affect it profoundly.

\section{Funding for Higher Education}

Until the 1960s, government funding for higher education in Quebec was notoriously meager. Ninety years after McGill's founding, appeals for funding were finally heeded in 1911/12, when Quebec granted \$3,000 in support of teacher training. That same year, Ontario's grant to the University of Toronto was $\$ 1 \mathrm{M}$. By 1949, McGill's grant had risen to
$\$ 132,000$ annually, or $4 \%$ of the operating budget. In the 1940 s, grants from other provinces to their universities were approximately $40 \%$ of annual budgets. Between 1932 and 1949, McGill received provincial grants totalling $\$ 2,379,167$, whereas Université de Montréal received \$13,832,707, and Université Laval $\$ 5,408,262$, despite having a combined 1947/48 enrolment lower than McGill's 7,756. Separate provincial grants were made to collèges classiques, which operated effectively as the undergraduate faculties of arts for the three francophone universities to which most colleges were affiliated. By comparison, McGill received no grant to cover the cost of undergraduate education, as it was judged to be the equivalent of a classical college program! ${ }^{9}$

When, in the 1950s, Premier Duplessis prohibited McGill and other Quebec universities from accepting federal money, J. W. McConnell (1877-1963) - a senior member of the Board of Governors-cautioned against engaging in a constitutional and political confrontation with the wily Premier whose position was too strong to be resisted. McConnell used his considerable powers of persuasion to convince the Premier that Quebec would have to compensate for the loss of federal university funding by developing a provincial granting scheme for higher education. Between 1954 and 1957, the University received $\$ 750,000$ annually, rising to $\$ 1,832,900$ in 1960 . $^{10}$

With Quebec's Quiet Revolution of the 1960s, and settlement of the jurisdictional dispute with Ottawa, provincial support for university operating and capital budgets improved dramatically. The operating grants were, however, unpredictable, and even capricious from McGill's perspective. Between 1961/62 and 1964/65 per student grants for the three French-language universities increased from $\$ 977$ to $\$ 1,295$, or $33 \%$, but for the three Englishlanguage universities declined from $\$ 586$ to $\$ 522$, or $11 \%$. From 1961 to 1966 McGill's enrolment rose by 45\%, staff $59 \%$, and operating expenditures $80 \%$, but Quebec operating grants by only $45.3 \%$. Indeed annual operating grants declined from $37.5 \%$ to $32.3 \%$ of total expenditures. Comparison of provincial grants between 1960/61 and 1966/67 for Université de Montréal, Laval, and McGill are revealing:

\begin{tabular}{|l|l|l|l|l|}
\cline { 2 - 5 } \multicolumn{1}{l|}{} & $1960 / 61$ & $1966 / 67$ & $\$$ Increase & $\%$ Increase \\
\hline Montréal & $\$ 5,412,370$ & $\$ 16,697,000$ & $\$ 11,284,630$ & $208 \%$ \\
\hline Laval & $\$ 3,878,105$ & $\$ 13,268,500$ & $\$ 9,390,395$ & $242 \%$ \\
\hline McGill & $\$ 5,175,514$ & $\$ 7,619,000$ & $\$ 2,443,486$ & $47 \%$ \\
\hline
\end{tabular}


As a result, McGill's faculty salaries were relatively low, tuition fees became the highest in the country, and a financial campaign was launched to balance the budget. ${ }^{11}$

During a 1971 television interview, Quebec's first Minister of Education (1964-1966) Paul Gérin-Lajoie provided the following explanation of the situation:

"McGill University had had the advantage of getting a lot of money from private sources at a period when the business establishment in Montreal was entirely English-speaking or very predominantly Englishspeaking...So some compensation had to be made by the public authority, by the government...There was a formula established. It was not intended to discriminate against any universities, not against McGill more than against any other universities, but it was intended to take into account the private sources of money of the universities and since McGill was the one having such large sums of private sources as compared to other universities in the province, well McGill suffered."

(Transcription from videotaped interview with the Honourable Paul Gerin-Lajoie broadcast over CBC "Hourglass", February 23, 1971) ${ }^{12}$

Gérin-Lajoie had overlooked the fact that inadequate public funding throughout its history had left McGill with no alternative but to solicit private funds. Also overlooked, was that McGill along with other non-Roman Catholic Anglophone institutions did not receive the services of clergy whose financial compensation was significantly lower than that received by lay people.

In 1965 and 1968 the province agreed to longstanding requests by McGill and other provincial universities for intermediary bodies that would recommend financial grants and lessen the likelihood of political controversy and breaches of academic freedom. Two committees were established: (i) Commission de l'aide à l'enseignement universitaire/Finance Sub-committee on Operating Budgets and (ii) Sous-comité des budgets universitaires de fonctionnement/University Investments Sub-committee on Capital Expenditures. They were composed of representatives from the three English and three French-language universities plus representatives from Ėcole polythechnique and Ėcole des hautes études commerciales-in addition to high-ranking provincial civil servants, and chaired by Germain Gauthier, Directeur général, Direction générale de l'enseignement supérieur, Ministère de l'education/ Director General, Directorate of Higher Education, Department of Education. ${ }^{13}$

The Capital Expenditures Sub-committee worked reasonably well, despite university representatives being denied voting power and instances of the government overturning recommendations. Even so, McGill's massive building and renovation projects proceeded successfully, combing government grants with significant private benefactions-such as Isabella McLennan's bequest permitting construction of a new library building. Of the $\$ 150 \mathrm{M}$ spent between 1960 and 1975, \$83M came from the government of Quebec, $\$ 57 \mathrm{M}$ from private sources (graduates, benefactors, and corporations) and $\$ 15.5 \mathrm{M}$ from the government of Canada. ${ }^{14}$

Much greater concern emerged, however, with the Committee on Operating Budgets-usually referred to as the Gauthier Committee. Although the committee made reasonable recommendations, the government would regularly alter them to serve its own political agenda-sometimes to McGill's advantage but usually not. On the one hand, the government would sometimes reverse its own decisions and admit its error, or sometimes provide additional support for such things as the University's CEGEP program. On the other hand, annual protests by McGill became the norm.

In 1966, McGill was penalized much more heavily than other universities when Quebec City reduced each university's grant by $71 / 2 \%$, calculated upon its "total anticipated expenditure" including money received either from outside research granting agencies or from endowments. As McGill received significant amounts from these sources, it was more severely penalized than other universities. To its credit, however, the government would largely reverse this decision. In 1968, McGill was penalized again by the government's decision to base increases upon projected increases in enrolment. In 1969, the government reversed Gauthier's recommendation and reduced total university grants by $3.9 \%$ with McGill's reduction being $11.7 \%$ or $\$ 2.97 \mathrm{M}$, later revised to $\$ 2.5 \mathrm{M}-$ more than the combined reductions sustained by all other Quebec universities and equal to McGill's investment income and donations. The official reason for McGill's reduction was for running a deficit the previous year and spending beyond its allowed ceiling for expenditures. What was particularly worrying was perstudent funding from all sources - grants, fees, endowments, and donations - now being less for English-language than for French-language universities: Laval \$2,242, Université de Montréal \$2,249, McGill \$1,356 and Sir George Williams $\$ 1,059.15$

Principal Robertson and his Executive Assistant, G. A. Grimson, identified five major arguments used against McGill that supported funding discrepancies, to which they also provided their rebuttals. ${ }^{16}$

First, "rattrapage" - "catch up" - funding was required by Francophone institutions, for which McGill should be prepared to sacrifice.

Although agreeing wholeheartedly that additional support for other universities was justified, McGill did not understand why it should be at the University's expense. Some observers commented 
on the thin line between "catching up" and "fattening up"!

Second, McGill was "scandalously" prosperous through the support of wealthy Anglophones.

Robertson and Grimson pointed to the major discrepancy in per student funding from all sources between McGill and Francophone universities.

Third, the University's deficits should be covered by liquidating its large endowment.

McGill pointed out that a relatively small proportion was unrestricted, whereas the bulk was restricted to producing income whose expenditure was legally limited to specific uses or activities. What universities really needed were incentives to increase efficiency and raise additional funds. If McGill had to liquidate its endowment, other universities should also have to do the same.

Fourth, McGill's education of students from outside the province should not be at Quebec's expense.

The majority-75\% - of McGill's students were from within the province, Robertson said, with only $10 \%$ from other provinces and 15\% from outside the country. Having foreign and out-of-province students was enriching for McGill and Quebec. Furthermore, Quebec should keep in mind the large number of its own students being educated in other provinces and countries.

Fifth, the University's research activities brought sufficient extra funding to cover its needs.

Robertson, himself a prominent researcher, was incensed by criticism of what he considered a core McGill value and strength. Far from bringing additional financial support to the University, research entailed additional costs. Of the $\$ 10,894,226$ in $1965 / 66$ research grants, only $1.8 \%$ or $\$ 193,150$ was designated for overhead operating costs.

In dealing with Quebec City and its bureaucracy the art of negotiation was mastered slowly through trial and error, employing a combination of quiet diplomacy and public confrontation. In private meetings with Premiers Lesage, Johnson, and Bertrand and their advisors, Principal Robertson and his advisors found themselves constantly at a disadvantage. The government's position was characterized by cordiality, sincere regret at funding discrepancies, assurances of future improvement, and a desire to avoid public controversy. The University, for its part was constantly having to correct misunderstanding and misrepresentation about its financial reality and legitimate needs. ${ }^{17}$

One example was an urban myth suggesting that McGill possessed secret caches of money above and beyond those reported in its financial statements, and therefore didn't deserve government support, which the University tried to counter through private diplomacy. The situation came to a head in February 1968 when a confidential report leaked to the French-language press suggested that McGill's grant would be greatly increased. In response, a few weeks later Quebec's three English-language universities-McGill, Bishop's and Sir George Williams-made public what they considered discriminatory and unjust treatment. Principal Robertson was immediately rebuked by the Minister of Education, Jean-Guy Cardinal, for breaching confidentiality. The minister held that

"...one of the basic conditions for maintaining good relationships between the universities and the Department of Education should be to observe the rules that have been mutually agreed upon."

Press reaction to the plight of McGill and the other English language universities was international, national, and provincial. Of particular interest was Vincent Prince's editorial in Montreal's French-language newspaper of elite opinion, Le Devoir. Although conceding that the claims of McGill and the other Anglophone universities had some justification, Prince went on to argue the importance of "rattrapage" for Francophone universities in raising their standards and ability to serve Quebec's majority community. While the Anglophone community accounted for only 13\% of the province's population-bolstered to $20 \%$ with NeoCanadian Anglophones not of English/British ethnicity or descent-it accounted for $40 \%$ of university enrolment. For English-language universities to receive, therefore, $30 \%$ of provincial grants, was a reasonable compromise, as was deducting gifts and endowment income from their grants. Francophone institutions had to be strengthened and expanded to ensure that they attracted both a higher proportion of Quebec's French-speaking population and also more foreign and out-of-province students.

Overlooked in Prince's analysis was how the Anglophone tradition of undergraduate streams had resulted in proportionally higher enrolment at the university level, whereas the Francophone tradition of not having undergraduate university streams resulted in high collège classique enrolment. Within one year, however, phasing out of the collèges was completed, and CEGEP graduates began flowing into newly created undergraduate programs. Francophone universities, bolstered by the Université du Québec system, would experience surging enrolment that would far surpass Anglophone enrolment, both absolutely and proportionally. Nevertheless attitudes, perceptions, and funding precedents - frequently disadvantageous to McGill-were established that would continue into the 2000s. ${ }^{18}$ 


\section{Language of Education}

When the decade opened, language of education in Quebec continued to be, as had long been the case, a personal choice with the decision determined largely by religion: Francophones attending Catholic schools and Anglophones attending Protestant schools. Exceptions were of no particular concern until the post World War II era when mass education came to Quebec along with large numbers of immigrants - many of whom were Roman Catholic who preferred, or were encouraged, to attend English-language schools; impediments to attending French-language schools were often encountered. As a result, the Protestant system and the English-language sector of the otherwise Frenchlanguage Roman Catholic system began expanding. As the 1960s progressed, however, concern for survival of the province's Francophone majority and Quebec's status in Canada became fused with the issue of language of education. A public dispute erupted over plans to provide Englishlanguage Roman Catholic education to children of Italian immigrants and their descendents living in the Montreal suburb of St. Leonard. Highly vocal groups advocated that "neo-Canadians" be required to attend French-language schools; others advocated the complete elimination of English-language education from the province. Provincial Bill 85 meant to settle this issue by emphasizing "French as Quebec's priority language while pressing individual linguistic freedom of choice in Education" was withdrawn in the face of nationalist opposition. In 1969, Bill 63, passed over strong opposition, asserted priority of French but permitted parents to choose whether their children would be educated in French or English. By now, language had emerged as a major issue across Canada, leading to the recommendations of the (Laurendeau-Dunton) Royal Commission on Bilingualism and Biculturalism, being embodied by Parliament in the 1969 Official Languages Act, whereby both English and French had equal status as national languages. ${ }^{19}$

\section{Opération McGill Français}

On Friday March 28, 1969, funding for higher education and language of education merged as a single issue that came crashing down upon McGill, when 10,000 chanting demonstrators participated in a "manifestation" on Sherbrooke St. outside the Roddick Gates-Opération McGill français. This remarkable event stands as a defining moment in McGill-Quebec relations, and was unprecedented in the history of Quebec/Canadian higher education. The immediate issue precipitating the manifestation was a widespread misperception-only slowly corrected by politicians and officials - that 10,000 francophone graduates from newly created CEGEP would be excluded in the autumn from higher education due to insufficient space in Frenchlanguage universities. Despite undergraduate programs developing on schedule at Montréal, Laval, and Sherbrooke as well as at the newly formed Université du Québec, radical voices urged that McGill be transformed into a Frenchlanguage university to handle the perceived shortage of student spaces. In addition, McGill was called upon to lower its academic entrance standards and permit public access to its library, the largest in Quebec.

Fringe elements advocating violence, such as le Front de liberation du Québec (FLQ) blended in with left wing groups such as le Comité Indepéndence-Socialisme (CIS), and sought to exploit the issue to their advantage-urging physical destruction of McGill as a way of cleansing Anglophone capitalism and colonialism from Quebec. McGill was characterized, and even demonized, as the embodiment of Anglophone capitalist owners dominating oppressed Francophone workers. Explicit threats of violence caused deep alarm, and led to evacuation of students, staff, and faculty from the campus, which was protected by a small band of officials and police.

Fear that McGill français might lead to serious violence is not surprising given the tenor of the times. In 1968, student demonstrations precipitated the resignation of France's President Charles de Gaulle. The same year, American President Lyndon B. Johnson-bowing to widespread public demonstrations-decided not to seek a second term; Rev. Martin Luther King Jr. and Senator Robert Kennedy were assassinated. In Montreal, where random terrorist bombs had detonated throughout the decade, Pierre Eliot Trudeau - recently become Prime Minister of Canada - was the focus of violent rioting during the June 24 St. Jean Baptiste parade. CEGEP students had paralyzed the system during an October 1968 strike. That December, the McGill Computer Data Centre was occupied by le Mouvement pour l'intégration scolaire, whose supporters chanted "McGill en français." ${ }^{\prime 20}$ February 1969 saw radical students seizing and destroying the computer facilities at Sir George Williams University over a charge of racism.

In the end, the chanting McGill francais crowd caused little or no damage. Many participants were merely sightseers wanting to participate in a drama. When the riot police began dispersal operations around 11:00 pm, aside from a few minor incidents, people left quickly and quietly. Last minute assurances by education officials that sufficient space would be available in September at Francophone universities did much to ease the situation. The situation may also have been eased by a tacit recognition among the throng, and Franco-Quebec society generally, that modernization of Francophone universities was based upon an Anglophone Canadian/Quebec model. Destroying McGill would have reflected badly upon Quebec, and deprived it of an important role model. Having McGill function as a Quebec university was more important than having it operate in French.

Reaction to Opération McGill français was mixed. The English-language community was generally critical, although 
there were pockets of support-primarily among radical groups. Within Quebec's Francophone community, criticism was muted with some political leaders being publicly critical but privately supportive. Quebec's French-language newspaper of elite opinion, Le Devoir, and its editor Claude Ryan-future leader of the Provincial Liberal Party and Minister of Education - took a widely supported position: condemning violence and supporting the legitimacy of English-language education within Quebec, while also arguing that McGill received more than its fair share of financial support. Inspired by McGill's Professor Laurier LaPierre, Ryan declared that McGill, "Celui-ci souhait qu'en plus dêtre au Québec, McGill soit aussi du Québec"-McGill must cease simply operating in Quebec but must become fully part of Quebec. ${ }^{21}$

Within McGill, there was also a range of reaction. The Students' Society of McGill University opposed the Opération, but a Political Science lecturer-Stanley Gray-became a major supporter and spokesman, which contributed to his dismissal after a lengthy public hearing. In fact, McGill had changed and accommodated itself during the '60s to Quebec's changing realities. In 1963 there were introduced: staff French language courses, and the French Canada Studies Program, expanded right of students to submit written work in French, and a policy of admitting larger numbers of Francophone students. In 1968, McGill established "A Committee on Translation and Language Use Problems". Even so, by 1970 only $10 \%$ of the student body was Francophone, and no francophone could be found among the Principal, Vice-Principals, Deans, and members of the Board of Governors. Among the administrative staff, Francophones accounted for $3.4 \%$, and bilingual staff for $23.4 \%$ of the total.

Following the events of March 28, there was struck "The Committee on the Use of French at McGill" whose report was summarized as follows: ${ }^{22}$

While the subcommittee's inability to present a language policy indirectly supports the status quo, the report does contain various proposals designed to increase the use of French within the Roddick Gates and to make the environment more comfortable for the French Canadian pursuing his studies at the University. The committee urges that:

All Administrators above the level of department chairman should be capable of understanding French and speaking a "tolerable" French;

Each office have one member of the clerical staff who possesses a good level of proficiency in French;

Public relations work be carried out in both languages;

Students be permitted to write term papers in French when such work constitutes a major portion of their final mark;
Development of language courses for both students and staff at the least possible cost to those taking the courses".

\section{Conclusion}

Crisis and achievement characterized the 1960s and Rocke Robertson's principalship of McGill University. His achievements included using newly available resources to construct and renovate much needed facilities, and rejuvenate teaching and research programs. Growing enrolment was accepted as McGill's contribution to the demands of mass education. Bureaucratic and administrative structures were created, reorganized, and strengthened to meet the requirements of growth and complexity. Governance was restructured along collegial lines to ensure that faculty, staff, students, and the larger public participated in decisionmaking. Adaptation to Quebec's changing linguistic and political realities occurred rationally and deliberately through offering a CEGEP program, and increasing bilingualism. In the face of strongly emerging competition, the University retained and strengthened its position as a leading Canadian and international university.

Crises accompanied all these activities and events, as change and innovation proved both invigorating and disruptive. Internally the Sherbrooke St. campus became a virtual construction site, with attendant dislocation. Newly hired professors and revised curricula raised hackles among the faculty, as familiar faces and classes disappeared and new ideas and programs emerged. Bureaucracy and administrators aroused academic irritation and antipathy. Although governance was revamped with remarkable ease, its prelude involved significant faculty agitation, and student protest - even violence that resulted in the RCMP labeling McGill a hotbed of radicalism. Externally, provincial funding for McGill emerged as a politicized issue surrounded by uncertainty and insecurity, as did language of education. Combined, the two issues-language and funding - resulted in the greatest threat ever faced by the University: Opération McGill francais. Violence and threats of violence were etched into McGill's psyche, leaving a residue of trepidation and wariness that would linger well beyond the ' $60 \mathrm{~s}$.

Perhaps McGill's greatest achievement of the decade was undergoing fundamental change and reorganization while avoiding internecine warfare. In laying the foundation for internal social peace the University was able to focus, over the coming decades, upon its primary academic mission, teaching and research, attracting quality students, and finding the resources to fund these activities. As it left the '60s and entered the 1970s, welcoming a new principal, McGill faced numerous challenges and opportunities:

1. Reconciling its national and international reputation for academic achievement with the demands of mass education; 
2. Pondering the source of student enrolment in the face of Quebec's demographically declining Englishlanguage community;

3. Determining its role within Quebec's new system of higher education, including CEGEPs;

4. Gauging the impact on higher education of Quebec's newly emerging focus upon priority for the French language;

5. Ensuring financial viability in light of provincial funding priorities;

6. Observing the effectiveness of newly created administrative and bureaucratic structures;

7. Monitoring the effectiveness of collegial governance systems in providing a sense of community and unity of purpose required to avoid internecine warfare, and

8. Facing effectively the challenge of producing academic excellence within a volatile and unpredictable environment.

\section{ENDNOTES}

${ }^{1}$ Board of Governors. Confidential Minutes. June 25, 1970. Document 58A

${ }^{2}$ The following provide background for this chapter:

Michael D. Behiels, Quebec since 1945. Toronto, Copp Clark, 1987; Alain Gagnon, et al. Quebec: beyond the Quiet Revolution. Scarborough, Nelson, 1990; Peter Gossage, An Illustrated History of Quebec: Tradition E Modernity. Toronto, OUP, 2012; Paul-André Linteau, Quebec since 1930. Toronto, Lorimer, 1991; Sean Mills, The Empire Within: Postcolonial Thought and Political Activism in Sixties Montreal. Montreal, McGill-Queen's, 2010; Desmond Morton, A Short History of Canada. $6^{\text {th }}$ ed. Toronto, McClelland \& Stewart, 2006; H. V. Nelles, A Little History of Canada. $2^{\text {nd }}$ ed. Toronto, OUP, 2011; Brian Young, A Short History of Quebec. $4^{\text {th }}$ ed. Montreal, McGill-Queen's, 2008.

${ }^{3}$ Claude Galarneau, Les collèges classiques au Canada français [1620-1970]. Montréal, Fides, 1978; Sidney M. Gershberg, "Pressure Group Politics; the Case of the Federation of Classical Colleges". McGill University, MA Thesis (Economics and Political Science) 1968; Magnuson, Roger P. The Two Worlds of Quebec Education during the Traditional Era, 1760-1940. London, ON, Althouse Pr, 2008. Chapters 6, 10; Report of the Royal Commission of Inquiry on Education in the Province of Québec. Quebec, The Commission, 1963-[67]. 3 pts. in 5 and index. (Part Two A, p. 196-209); "Subcommittee on University Operating Expenditures, the 'Collegial' level, a position paper by S. Frankel" May 30, 1967. RG3, c52, file 873.

${ }^{4}$ Robin Harris, A History of Higher Education in Canada, 1663-1960. Toronto, U of T Pr, 1976. p. 454-464.

${ }^{5}$ Stanley Brice Frost, McGill University: for the Advancement of Learning. Montreal, McGill-Queen's, 1984. v. II, Chapter 14; "McGill University Response to the 'Orientations' Questionnaire of the Council of Universities." June 1971. RG3, c105, file 1696, p. 2-3.

${ }^{6}$ MacKay L. Smith, Memories and Profiles of McGill University: Downtown Campus, 1798-2009. Montreal, Infinitebooks, 2009. Chapters 7, 8, 9.

${ }^{7}$ Frost, McGill University, II, p. 435-9.

${ }^{8}$ Frost, McGill University. II, Chapter 15; McGill Association of University Teachers. Website. [http://maut.mcgill.ca/] October 1, 2009; University
Government in Canada: Report of a Commission Sponsored by the Canadian Association of University Teachers and the Association of Universities and Colleges of Canada. Commission: Sir James Duff, Robert O. Berdahl. Toronto, Published for the Associations by University of Toronto Press, 1966.

9"Report to the Faculty by Dr. H. Rocke Robertson, Principal and ViceChancellor, December 12, 1966", RG3, c52, file873, p. 3, Appendix 4, "Exclusive of Expenditures on...Agriculture, Household Science, and the Training of Teachers...Exclusive of Grants to the Classical Colleges... faculties of Arts...Laval and Montreal"; Gwendoline Pilkington, Speaking With One Voice: Universities in Dialogue with Government. Montreal, History of McGill Project, McGill University, 1983. chapters III, IV, \& V.

${ }^{10}$ William Fong, J. W.McConnell: Financier, Philanthropist, Patriot. Montreal, McGill-Queen's, 2008. Chapter 17. Frost, McGill University. II, p. 251-253.

${ }_{11}$ "Quebec government grants to universities and classical colleges (as reported in Public Accounts and Budget Estimates) A. C. M. 16/2/66. Statements 1-6". RG3, c52, file877; "Report to the Faculty by Dr. R. H. Robertson, Principal and Vice-chancellor, Monday December 12, 1966" RG3, c52, file873.

12“Memorandum on McGill's Financial Situation." August, 1971. RG3, c327, file 7800 .

${ }^{13}$ "Quebec government grants to universities and classical colleges. Statement 2" RG3, c52, file877; "Translation of a letter...to...L A Vachon... by Jean-Guy Cardinal" February 28, 1968. RG3, c52, file874; "University Grants Commission." RG2, c269. file8110; Montreal Gazette July 22, 1960, p. 1; "Grants: Provincial Grants: Quebec University Grants Commission" RG2, c269, files 8110, 8114 .

${ }^{14}$ Frost, McGill University. II, p. 432; G. A. Grimson letter to Pierre-Paul Proulx, June 19, 1969. RG2, c354, file13095; Peter F. McNally, "McLennan Library: Twenty-Fifth Anniversary." Fontanus: from the Collections of McGill University, v. VII (1994), p. 152-155.

15“Notes on Allocation of Grants 1966-67" December, 1966; "Meeting with Hon. P. Dozois" January 17, 1967; "Report of Sub-committee on Operating Budgets, 1967-68, General Comments, McGill University. January 23, 1967. RG3, c52, file 873. "Discussions with Mr. Johnson-March 13, 1968" RG3, c52, file 875 .

16"Report to the Faculty by Dr. R. H. Robertson, Principal and Vicechancellor, Monday December 12, 1966" RG3, c52, file873; "Some Notes by Dr. H. Rocke Robertson on Rattrapage” 29 December, 1967. RG3, c52, file878; "Comments on the Experience of the Sub-Committee on Operating Budgets (Gauthier Committee) circa 1969. RG2, c354, file13095.

${ }_{17}$ "Memo on Meeting with Prime Minister Daniel Johnson, Chancellor and later M. Jean-Guy Cardinal and M. Marcel Faribault, 14 Mar/68". RG3, c52, file874; "Discussion with Mr. Johnson, March 13, 1968; "Memorandum for interview with Prime Minister Jean-Jacques Bertrand, 28 April, 1969” RG3, c52, file875.

${ }^{18}$ Lysiane Gagnon, "Nouveau bond gigantesque en 1968 des subventions accordé à McGill." La Presse, fev. 10, 1968, p. 1-2. "McGill, Sir George, Bishop's Protest '68-'69 Operating Grants." McGill Bulletin, no. 15, April 15, 1968, RG3, c52, file874; Letter from Cardinal to Robertson, April 3, 1968. RG3, c52, file1874; Vincent Prince, "L'universités anglophones du Québec sont-elles victimes d'une injustice?” Le Devoir, avril 1, 1968, editorial page; See also newspaper clippings in RG3, c327, file7800.

${ }^{19}$ Marc V. Levine, The Reconquest of Montreal: Language Policy and Social Change in a Bilingual City. Philadelphia, Temple University Press, 1990. Chapter 4.

${ }^{20}$ Frost, McGill University. II, p. 458.

21"McGill français: 30 ans après." Cahiers du PEEQ [Programme détudes sur le Québec], no. 20, janvier, 2001. (Claude Ryan, "McGill français: 30 ans après." p. 17-20)

22"McGill français: 30 ans après." (Ginette Lamontagne, "McGill et le fait français de 1969 à 1999: de la coexistence à la francophilie." p. 23-28) 